\title{
EFEK SISTEM OLAH TANAH DAN PEMBERIAN HERBISIDA TERHADAP KARBON TERSIMPAN DI ATAS PERMUKAAN TANAH PADA PERTANAMAN JAGUNG (Zea mays L.) MUSIM TANAM KE- 3
}

\author{
Tartila Fajar Masryfah ${ }^{1)}$, Irwan Sukri Banuwa ${ }^{2)}$, Henrie Buchari' ${ }^{2)}$, Muhajir Utomo $^{2)}$ \\ ${ }^{1}$ Mahasiswa Jurusan Agroteknologi, Fakultas Pertanian, Universitas Lampung \\ ${ }^{2}$ Dosen Jurusan Agroteknologi, Fakultas Pertanian, Universitas Lampung \\ J1 Sumantri Brojonegoro 1, Bandar Lampung 35145, Indonesia \\ Email: tartilafajar1@gmail.com
}

\begin{abstract}
ABSTRAK
Penelitian ini bertujuan untuk mengetahui pengaruh (1) sistem olah tanah pada lahan pertanaman jagung terhadap C tersimpan di atas permukaan tanah; (2) pemberian herbisida pada pertanaman jagung terhadap C tersimpan di atas permukaan tanah; (3) interaksi anara sistem olah tanah dan pemberian herbisida terhadap C tersimpan di atas permukaan tanah. Penelitian ini dilaksanakan padaOktober 2016 sampai Februari 2017 di Laboratorium Lapang Terpadu danLaboratorium Ilmu Tanah, Fakultas Pertanian, Universitas Lampung. Rancanganyang digunakan yaitu rancangan faktorial dalam Rancangan Acak Kelompok Lengkap(RAKL) pada dua faktor perlakuan yaitu sistem olah tanah dan pemberian herbisida dengan empat kali ulangan. Hasil penelitian menunjukkan bahwa (1) Biomassa gulma dan serasah, C-tersimpan gulma dan serasah, dan produksi tanaman jagung pada olah tanah minimum tidak berbeda dibandingkan olah tanah penuh, tetapi pada biomassa tanaman, biomassa total di atas permukaan tanah, C-tersimpan tanaman, C-tersimpan total di atas permukaan tanah dan serapan karbon berbeda;(2)Biomassa tanaman, biomassa total di atas permukaan tanah dan C-tersimpan tanaman pada perlakuan pemberian herbisida tidak berbeda dibandingkan tanpa pemberian herbisida, tetapi pada biomassa gulma dan serasah, C-tersimpan gulma dan serasah, C-tersimpan total di atas permukaan tanah, serapan karbon, dan produksi tanaman jagung; (3)Tidak ada interaksi yang terjadi antara perlakuan sistem olah tanah dan herbisida terhadap biomassa tanaman, biomassa gulma dan serasah, biomassa total di atas permukaan tanah, C-tersimpan tanaman, C-tersimpan gulma dan serasah, C-tersimpan total di atas permukaan tanah, serapan karbon, dan produksi tanaman jagung.
\end{abstract}

Kata kunci: C tersimpan, herbisida, olah tanah.

\section{PENDAHULUAN}

Biomassa sangat relevan dengan isu perubahan iklim serta berperan penting dalam siklus karbon (Brown, 1997). Biomassa juga merupakan indikator penting dalam penyerapan karbon, sehingga dapat diketahui berapa banyak biomassa yang hilang atau terakumulasi dari waktu ke waktu (Parresol, 1999). Cadangan karbon adalah kandungan karbon tersimpan baik itu pada permukaan tanah sebagai biomassa tanaman,sisa tanaman yang sudah mati (nekromasa), maupun dalam tanah sebagai bahan organik tanah.Perubahan wujud karbon ini kemudian menjadi 
dasar untuk menghitung emisi, dimana sebagian besar unsur karbon $(\mathrm{C})$ yang terurai ke udara biasanya terikat dengan $\mathrm{O}_{2}$ (oksigen) dan menjadi $\mathrm{CO}_{2}$ (karbon dioksida). Itulah sebabnya ketika satu hektar hutan menghilang (pohon-pohonnya mati), maka biomassa pohon-pohon tersebut cepat atau lambat akan terurai dan unsur karbonnya teremisi (Kauffman, 2012).

Jumlah C tersimpan antar lahan berbeda-beda, tergantung pada keragaman dan kerapatan tumbuhan yang ada, jenis tanahnya serta cara pengelolaannya. Penyimpanan karbon suatu lahan menjadi lebih besar bila kondisi kesuburantanahnya baik, atau dengan kata lain jumlah karbon tersimpan di atas tanah(biomasa tanaman) ditentukan oleh besarnya jumlah karbon tersimpan di dalamtanah (bahan organik tanah, BOT) (Hairiah dan Rahayu, 2007). Selain itu banyaknya tanah yang tererosi dipengaruhi oleh banyak faktordan salah satunya adalah faktor vegetasi penutup tanah dan pengelolaan tanaman.Untuk itu pengukuran banyaknya Cyang ditimbun dalam setiap lahan perlu dilakukan.

Penyimpanan karbon oleh tanah merupakan salah satu cara untuk mengurangi akumulasi karbon di atmosfir. Permukaan tanah bumi dengan kedalaman 30 cm saja mengandung sekitar 800 giga ton karbon, masih lebih tinggi dari karbon atmosfir yaitu sebesar 730 gigaton, dan vegetasi di permukaan bumi sebesar 470-655 gigaton (Melfi,2005). Dengan demikian peran sumberdaya tanah dalam menyimpan karbon di sektor pertanian tanaman pangan menjadi strategis.

\section{BAHAN DAN METODE}

Penelitian ini dilakukan di Laboratorium Lapang Terpadu Fakultas Pertanian Universitas Lampung dan Laboratorium Ilmu Tanah Fakultas Pertanian Universitas Lampung. Penelitian dilakukan pada bulan Oktober 2016 sampai Februari 2017. Bahan-bahan yang digunakan dalam penelitian ini adalah Bahan yang digunakan adalah tanah,tanaman jagung sebagai vegetasi, pupuk urea,pupuk SP36, pupuk $\mathrm{KCl}$, kompos, herbisida glyfosat 2,4 D, sampel tanaman jagung, sampel tanaman bawah, K2Cr2O7, $\mathrm{H} 2 \mathrm{SO} 4$ pekat, akuades, $\mathrm{H} 3 \mathrm{PO} 4, \mathrm{NaF} 4 \%$, indikator difenilamin, dan ammonium ferosulfat. Alat-alat yang digunakan pada penelitian ini adalah petak erosi, meteran, kamera, tali, patok kayu, parang, kantong plastik, alat tulis, borang data tanaman, timbangan, oven dan alat-alat laboratorium untuk analisis tanah dan tanaman.

Penelitian petak eosi ini menggunakan Rancangan Faktorial 2x2 dengan 4 kali ulangan. Faktor pertama meliputi sistem olah tanah yakni M (pengolahan tanah minimum) dan F ( pengolahan tanah penuh), dan faktor kedua meliputi Herbisida yakni H1(pemberian herbisida), H0 (tanpa pemberian herbisida). Sehingga didapatkan 16 perlakuan. Percobaan disusun dalam Rancangan Acak Kelompok Lengkap (RAKL). Data yang diperoleh kemudian diuji homogenitas ragamnya dengan uji Bartlett, bila kedua asumsi terpenuhi data diuji kemenambahannya dengan uji Tukey. Bila kedua asumsi terpenuhi data dianalisis ragam dan dilakukan pemisahan nilai tengah dengan uji (BNT) pada taraf $5 \%$. 
Penelitian ini merupakan penelitian lanjutan dan merupakan penelitian pada musim tanam ketiga. Penelitian musim tanam pertama dilaksanakan pada bulan Januari 2014 sampai dengan bulan April 2014 dengan tanamannya adalah jagung. Penelitian selanjutnya dilaksanakan pada bulan Mei 2014 sampai dengan bulan April tahun 2015 dengan tanamannya adalah singkong. Pada musim tanam kedua dilaksanakan pada bulan Mei 2015 sampai Agustus 2015 dengan tanamannya adalah jagung. Kemudian pada bulan Oktober 2015 sampai September 2016 dilakukan penelitian dengan tanaman singkong. Penelitian musim ketiga ini dilaksanakan pada bulan Oktober 2016 sampai dengan bulan Februari 2017 dengan tanamannya adalah jagung. Dalam penelitian ini terdapat beberapa tahap yang dilakukan yaitu pengolahan tanah, budidaya tanaman ( perawatan dan pemeliharaan), pengamatan dan pengambilan data.

\section{HASIL DAN PEMBAHASAN}

\section{Rekapitulasi Analisis Ragam dari Setiap Variabel Pengamatan}

Hasil penelitian menunjukkan bahwa biomassa total di atas permukaan tanah pada perlakuan olah tanah berbeda nyata sedangkan pada pemberian herbisida tidak berbeda nyata. Biomassa total di atas permukaan tanah merupakan hasil dari penjumlahan biomassa tanaman dan biomassa komponen (gulma dan serasah) perlakuan sistem olah tanah nyata mempengaruhi biomassa tanaman jagung, sedangkan perlakuan herbisida serta interaksi keduanya tidak berpengaruh nyata terhadap biomassa tanaman jagung. Pada perlakuan olah terhadap biomassa tanaman jagung, olah tanah minimum lebih tinggi yaitu sebesar 29,08 ton/ha dan olah tanah minimum yaitu sebesar 19,18 ton/ha.

Olah tanah minimum nyata mempengaruhi biomassa tanaman jagung, hal tersebut dikarenakan pengolahan tanah minimum dapat menciptakan kondisi

Tabel 1. Rekapitulasi analisis ragam dari setiap variabel pengamatan

\begin{tabular}{lllcc}
\hline \multirow{2}{*}{ No. } & Variabel Pengamatan & \multicolumn{2}{l}{ Pengaruh } & \\
& & Faktor & \multicolumn{2}{c}{ OtxH } \\
\hline 1 & Biomassa Tanaman (ton/ha) & OT & H & \\
2 & Biomassa Gulma dan serasah (ton/ha) & $*$ & tn & tn \\
3 & Biomassa Total di Atas Permukaan Tanah (ton/ha) & tn & $*$ & tn \\
4 & C-Tersimpan Tanaman (ton C/ha) & $* *$ & tn & tn \\
5 & C-Tersimpan Gulma dan serasah (ton C/ha) & $* *$ & tn & tn \\
6 & C-Tersimpan Total di Atas Permukaan Tanah (ton C/ha) & tn & $*$ & tn \\
7 & Serapan Karbon (ton $\mathrm{CO}_{2} /$ ha) & $* *$ & $*$ & tn \\
8 & Produksi Jagung (ton/ha) & $* *$ & $*$ & tn \\
\hline
\end{tabular}

Keterangan: $\mathrm{OT}=$ Olah tanah; $\mathrm{H}=$ Herbisida; $\mathrm{OtxH}=$ Interaksi olah tanah dan herbisida; $\mathrm{tn}=$ Tidak berbedanyata pada taraf $=0,05 ; *$ dan $* *=$ masing-masing berbeda nyata dan sangat nyata pada taraf $=0,05$ dan 0,01 
tanah yang baik bagi perkembangan akar, sehingga akar dapat menyerap unsur-unsur hara yang tersedia yang pada akhirnya akan meningkatkan pertumbuhan dan produksi tanaman jagung. Hasil analisis ragam menunjukkan bahwa perlakuan sistem olah tanah tidak nyata mempengaruhi biomassa gulma dan serasah, Ctersimpan gulma dan serasah, produksi jagung

\section{Pengaruh Sistem Olah Tanah Dan Herbisida Terhadap Biomassa Tanaman Jagung}

Hasil penelitian menunjukkan bahwa perlakuan sistem olah tanah minimum nyata mempengaruhi biomassa tanaman sebesar 29,08 ton/ha, sedangkan pemberian herbisida tidak nyatamempengaruhi biomassa tanaman jagung. Interaksi antara sistem olah tanah dan pemberian herbisida tidak nyata mempengaruhi biomassa tanaman jagung.

\section{Pengaruh Sistem Olah Tanah dan Herbisida Terhadap Biomassa Gulma dan Serasah}

Pengaruh perlakuan sistem olah tanah dan herbisida terhadap biomassa gulma dan serasah menunjukkan bahwa perlakuan sistem olah tanah tidak nyata mempengaruhi biomassa gulma dan serasah, sedangkan pemberian herbisida nyata mempengaruhi biomassa gulma dan serasah sebesar 7,08 ton/ha. Interaksi antara sistem olah tanah dan pemberian herbisida tidak nyata mempengaruhi biomassa gulma dan serasah. Perlakuan herbisida terhadap biomassa gulma dan serasah yaitu sebesar 7,08 ton/ha lebih tinggi

Tabel 2. Pengaruh sistem olah tanah dan herbisida terhadap biomassa tanaman jagung

\begin{tabular}{cc}
\hline Perlakuan & Biomassa tanamanjagung (ton/ha) \\
\hline F & $19,18 \mathrm{~b}$ \\
M & $29,08 \mathrm{a}$ \\
\hline H0 & $23,51 \mathrm{a}$ \\
H1 & $24,76 \mathrm{a}$ \\
\hline BN T $(5 \%)$ & 7,02
\end{tabular}

Keterangan: $\quad \mathrm{F}=$ olah tanah penuh, $\mathrm{M}=$ olah tanah minimum, $\mathrm{H} 0=$ tanpa herbisida, $\mathrm{H} 1=$ pemberian herbisida. Nilai tengah pada tabel yang diikuti oleh huruf yang sama tidak berbeda nyata berdasarkan Uji BNT taraf $5 \%$.

Tabel 3. Pengaruh sistem olah tanah dan herbisida terhadap biomassa gulma dan serasah

\begin{tabular}{cc}
\hline Perlakuan & Biomassa gulma dan serasah (ton/ha) \\
\hline F & $5,32 \mathrm{a}$ \\
M & $5,51 \mathrm{a}$ \\
\hline HO & $3,76 \mathrm{~b}$ \\
H1 & $7,08 \mathrm{a}$ \\
\hline
\end{tabular}

BNT (5\%) 2,98

Keterangan: $\mathrm{F}=$ olah tanah penuh, $\mathrm{M}=$ olah tanah minimum, $\mathrm{H} 0=$ tanpa herbisida, $\mathrm{H} 1=$ pemberian herbisida. Nilai tengah pada tabel yang diikuti oleh huruf yang sama tidak berbeda nyata berdasarkan Uji BNT taraf $5 \%$. 
dibandingkan tanpa herbisida (H0) yaitu sebesar 3,76 ton/ha. Sedangkan pada perlakuan olah tanah memberikan pengaruh yang sama terhadap biomassa gulma dan serasah, olah tanah minimumyaitu sebesar 5,51 ton/ha dan olah tanah penuh yaitu sebesar 5,32 ton/ha.

\section{Pengaruh Sistem Olah Tanah dan Herbisida Terhadap C-Tersimpan Tanaman Jagung}

Pengaruh perlakuan sistem olah tanah dan herbisida terhadap C-tersimpan tanaman perlakuan sistem olah tanah minimum nyata mempengaruhi Ctersimpan tanaman jagung sebesar 10,80 ton/ha, sedangkan pemberian herbisida tidak nyata mempengaruhi C-tersimpan tanaman jagung. Interaksi antara sistem olah tanah dan pemberian herbisida tidak nyata mempengaruhi $\mathrm{C}$-tersimpan tanaman jagung. Perlakuan sistem olah tanah minimum nyata mempengaruhi C-tersimpan tanaman jagung. Pengolahan tanah minimum dengan penutupan mulsa $30 \%$ sampai $60 \%$ dapat melindungi permukaan tanah dari cahaya matahari langsung, mengendalikan kelembaban tanah dan suhu tanah serta menciptakan kondisi tanah yang tidak terlalu gembur sehingga mikroorganisme berkembang lebih aktif dan menjadi sumber bahan organik tanah apabila mati. Pada kondisi demikian perkembangan akar lebih maksimal yang jika mati juga menjadi sumber bahan organik tanah. Sesuai dengan pendapat Sarief(1989) bahwa, makin baik tata air dan udara tanah maka aktivitas mikroorganisme

Tabel 4. Pengaruh sistem olah tanah dan herbisida terhadap C-tersimpan tanaman jagung

\begin{tabular}{cc}
\hline Perlakuan & C-tersimpan tanam an jagung (ton $\mathrm{C} / \mathrm{ha}$ ) \\
\hline $\mathrm{F}$ & $6,64 \mathrm{~b}$ \\
$\mathrm{M}$ & $10,80 \mathrm{a}$ \\
\hline H0 & $8,17 \mathrm{a}$ \\
H 1 & $9,27 \mathrm{a}$ \\
\hline BNT $(5 \%)$ & 2,13 \\
\hline
\end{tabular}

Keterangan: $\mathrm{F}=$ olah tanah penuh, $\mathrm{M}=$ olah tanah minimum, $\mathrm{H} 0=$ tanpa herbisida, $\mathrm{H} 1=$ pemberian herbisida. Nilai tengah pada tabel yang diikuti oleh huruf yang sama tidak berbeda nyata berdasarkan Uji BNT taraf 5\%.

Tabel 5. Pengaruh sistem olah tanah dan herbisida terhadap C-tersimpan Gulma dan serasah

\begin{tabular}{cc}
\hline Perlakuan & C-tersimpan gulma dan serasah (ton $\mathrm{C} / \mathrm{ha})$ \\
\hline F & $2,62 \mathrm{a}$ \\
M & $2,63 \mathrm{a}$ \\
\hline H0 & $1,81 \mathrm{~b}$ \\
H1 & $3,44 \mathrm{a}$ \\
\hline BN T $(5 \%)$ & 1,45 \\
\hline
\end{tabular}

Keterangan: $\mathrm{F}=$ olah tanah penuh, $\mathrm{M}=$ olah tanah minimum, $\mathrm{H} 0=$ tanpa herbisida, $\mathrm{H} 1=$ pemberian herbisida. Nilai tengah pada tabel yang diikuti oleh huruf yang sama tidak berbeda nyata berdasarkan Uji BNT taraf $5 \%$. 
dalam tanah semakin pesat. Menurut Parapasan, et al.,(1995) pada lahan yang diolah berlebihan menyebabkan pelapukan bahan organik berjalan cepat.

\section{Pengaruh Sistem Olah Tanah dan Herbisida terhadap C-Tersimpan Gulma dan Serasah}

Pengaruh perlakuan sistem olah tanah dan herbisida terhadap C-tersimpangulma dan serasah disajikan pada Tabel 5. Pada perlakuan sistem olah tanah tidak nyata mempengaruhi $\mathrm{C}$-tersimpan gulma dan serasah, sedangkan pemberian herbisida nyata mempengaruhi $\mathrm{C}$-tersimpan gulma dan serasah sebesar 3,44 ton $\mathrm{C} / \mathrm{ha}$. Interaksi antara sistem olah tanah dan pemberian herbisida tidak nyata mempengaruhi Ctersimpan gulma dan serasah. Jumlah serasah pada permukaan tanah sangat mempengaruhi penutupan permukaan lahan pada masing-masing penggunaan lahan.Ada korelasi positif antara jumlah serasah persatuan luas dengan tingkat penutupan lahan, artinya semakin bertambahnya jumlah serasah yang ada di permukaan lahan akan mengakibatkan meningkatnya presentase penutupan permukaan tanah (Monde,et al.,
2008). Berdasarkan penelitian ini diperoleh pada perlakuan herbisida berbeda nyata, sedangkan pada olah tanah tidak berbeda nyata.

\section{Serapan Karbon Dioksida $\left(\mathrm{CO}_{2}\right)$ oleh Tanaman Jagung}

Pengaruh perlakuan sistem olah tanah dan herbisida terhadap serapan karbon dioksida $\left(\mathrm{CO}_{2}\right)$ oleh tanaman jagung disajikan pada Tabel 6. Perlakuan sistem olah tanah minimum nyata mempengaruhi serapan $\mathrm{CO}_{2}$ sebesar 49,26 ton $\mathrm{CO}_{2}$ /ha, demikian pula pemberian herbisida nyata mempengaruhi serapan $\mathrm{CO}_{2}$, sebesar 46,63 ton $\mathrm{CO}_{2}$ /hatetapi tidak ada interaksi antara sistem olah tanah dan pemberian herbisida dalam mempengaruhi serapan $\mathrm{CO}_{2}$ oleh tanaman jagung. Perlakuan olah tanah minimum terhadap serapan $\mathrm{CO}_{2}$ lebih tinggiyaitu sebesar 49,26 $\mathrm{CO}_{2} /$ ha dibandingkan perlakuan olah tanah penuh yaitu sebesar 33,94 $\mathrm{CO}_{2} /$ ha, demikian pula pemberian herbisida terhadap serapan $\mathrm{CO}_{2}$ lebih tinggi yaitu sebesar 46,63 $\mathrm{CO}_{2}$ /ha dibandingkan perlakuan tanpa herbisida yaitu sebesar 36,57 $\mathrm{CO}_{2} /$ ha. Serapan karbon pada olah

Tabel 6. Pengaruh sistem olah tanah dan herbisida terhadap serapan $\mathrm{CO}_{2}$ oleh tanaman jagung

\begin{tabular}{cc}
\hline Perlakuan & Serapan $\mathrm{CO}_{2}\left(\right.$ ton $\mathrm{CO}_{2} /$ ha $)$ \\
\hline F & $33,94 \mathrm{~b}$ \\
M & $49,26 \mathrm{a}$ \\
\hline $\mathrm{H} 0$ & $36,57 \mathrm{~b}$ \\
$\mathrm{H} 1$ & $46,63 \mathrm{a}$ \\
\hline BNT $(5 \%)$ & 7,24 \\
\hline
\end{tabular}

Keterangan: $\quad \mathrm{F}=$ olah tanah penuh, $\mathrm{M}=$ olah tanah minimum, $\mathrm{H} 0=$ tanpa herbisida, $\mathrm{H} 1=$ pemberian herbisida. Nilai tengah pada tabel yang diikuti oleh huruf yang sama tidak berbeda nyata berdasarkan Uji BNT taraf 5\%. 
tanah minimum lebih tinggi dibandingkan dengan olah tanah penuh berkaitan erat dengan membaiknya iklim mikro pada sistem olah tanah minimum dibanding olah tanah penuh. Adanya mulsa pada lahan olah tanah minimum mampu meningkatkan kelembaban tanah sehingga dapat meningkatkan serapan hara tanaman (Utomo, 1989).

\section{Pengaruh Sistem Olah Tanah dan Herbisida terhadap Biomassa Total di Atas Permukaan}

Tanah

Pengaruh perlakuan sistem olah tanah dan pemberian herbisida terhadap biomassa total di atas permukaan tanah disajikan pada Tabel 7 yangmenunjukkan bahwa perlakuan sistem olah tanah minimum nyata mempengaruhi biomassa total di atas permukaan tanah sebesar 34,59 ton/ha, sedangkan pemberian herbisida tidak nyata mempengaruhi biomassa total di atas permukaan tanah. Interaksi antara sistem olah tanah dan pemberian herbisida tidak nyata mempengaruhi biomassa total di atas permukaan tanah.

\section{Pengaruh Sistem Olah Tanah dan Herbisida} terhadap C-Tersimpan Total di Atas Permukaan

\section{Tanah}

Pengaruh perlakuan sistem olah tanah dan herbisida terhadap C-tersimpantotal di atas permukaan tanah disajikan pada Tabel 8, menunjukkan bahwa perlakuan sistem olah tanah minimum nyata mempengaruhi C-tersimpan total di atas permukaan tanah sebesar 13,43 ton $\mathrm{C} /$ ha, demikian pula pemberian

Tabel 7. Pengaruh sistem olah tanah dan herbisida terhadap biomassa total di atas permukaan tanah

\begin{tabular}{cc}
\hline Perlakuan & Biomassa total di atas permukaan tanah (ton/ha) \\
\hline F & $24.50 \mathrm{~b}$ \\
M & $34.59 \mathrm{a}$ \\
\hline H0 & $27.26 \mathrm{a}$ \\
H 1 & $31.83 \mathrm{a}$ \\
\hline BN T $(5 \%)$ & 5,93 \\
\hline
\end{tabular}

Keterangan: $\mathrm{F}=$ olah tanah penuh, $\mathrm{M}=$ olah tanah minimum, $\mathrm{H} 0=$ tanpa herbisida, $\mathrm{H} 1=$ pemberian herbisida. Nilai tengah pada tabel yang diikuti oleh huruf yang sama tidak berbeda nyata berdasarkan Uji BNT taraf 5\%.

Tabel 8.Pengaruh sistem olah tanah dan herbisida terhadap C-tersimpan total di atas permukaan tanah.

\begin{tabular}{cc}
\hline Perlakuan & C-tersimpan total di atas permukaan tanah (ton C/ha) \\
\hline F & $9.26 \mathrm{~b}$ \\
M & $13.43 \mathrm{a}$ \\
\hline H $~$ & $9.97 \mathrm{~b}$ \\
H 1 & $12.72 \mathrm{a}$ \\
\hline B NT (5\%) & 1.97 \\
\hline
\end{tabular}

Keterangan: $\quad \mathrm{F}=$ olah tanah penuh, $\mathrm{M}=$ olah tanah minimum, $\mathrm{H} 0=$ tanpa herbisida, $\mathrm{H} 1=$ pemberian herbisida. Nilai tengah pada tabel yang diikuti oleh huruf yang sama tidak berbeda nyata berdasarkan Uji BNT taraf $5 \%$. 
Tabel 9. Pengaruh sistem olah tanah dan herbisida terhadap produksi jagung

\begin{tabular}{cc}
\hline Perlakuan & Produksi jagung (ton $/$ ha) \\
\hline F & $6.16 \mathrm{a}$ \\
M & $5.38 \mathrm{a}$ \\
\hline H0 & $4.72 \mathrm{a}$ \\
H1 & $6.82 \mathrm{~b}$ \\
\hline BNT $(5 \%)$ & 1.87 \\
\hline
\end{tabular}

Keterangan: $\quad \mathrm{F}=$ olah tanah penuh, $\mathrm{M}=$ olah tanah minimum, $\mathrm{H} 0=$ tanpa herbisida, $\mathrm{H} 1=$ pemberian herbisida. Nilai tengah pada tabel yang diikuti oleh huruf yang sama tidak berbeda nyata berdasarkan Uji BNT taraf 5\%.

herbisida nyata mempengaruhi C-tersimpan total atas permukaan sebesar 12,72 ton $\mathrm{C} / \mathrm{ha}$. Interaksi antara sistem olah tanah dan pemberian herbisida tidak nyata mempengaruhi C-tersimpan total di atas permukaan tanah. Mengukur jumlah Cyang disimpan dalam tubuh tanaman hidup (biomassa) pada suatu lahan dapat menggambarkan banyaknya $\mathrm{CO}_{2}$ di atmosfir yang diserap oleh tanaman.

\section{Pengaruh Sistem Olah Tanah dan Herbisida terhadap Produksi Jagung}

Pengaruh perlakuan sistem olah tanah dan pemberian herbisida terhadap produksi jagung disajikan pada Tabel 9 yang menunjukkan bahwa perlakuan sistem olah tanah tidak nyata mempengaruhi produksi jagung, sedangkan pemberian herbisida nyata mempengaruhi produksi jagung sebesar 6,82 ton/ha. Interaksi antara sistem olah tanah dan pemberian herbisida tidak nyata mempengaruhi produksi jagung.

\section{KESIMPULAN}

Berdasarkan hasil penelitian, dapat disimpulkan bahwa:

1. Biomassa gulma dan serasah, C-tersimpan gulma dan serasah, dan produksi tanaman jagung pada olah tanah minimum tidak berbeda dibandingkan olah tanah penuh, tetapi pada biomassa tanaman, biomassa total di atas permukaan tanah, Ctersimpan tanaman, C-tersimpan total di atas permukaan tanah dan serapan karbon berbeda.

2. Biomassa tanaman, biomassa total di atas permukaan tanah dan C-tersimpan tanaman pada perlakuan pemberian herbisida tidak berbeda dibandingkan tanpa pemberian herbisida, tetapi pada biomassa gulma dan serasah, C-tersimpan gulma dan serasah, C-tersimpan total di atas permukaan tanah, serapan karbon, dan produksi tanaman jagung.

3. Tidak ada interaksi yang terjadi antara perlakuan sistem olah tanah dan herbisida terhadap semua variabel pengamatan. 


\section{DAFTAR PUSTAKA}

Brown S. 1997. Estimating Biomass Change of Tropical Forest. A Forest Resources Assessment Publication. FAO Forestry Paper 134. Roma.

Hairiah, K., dan S., Rahayu. 2007. Pengukuran Karbon Tersimpan di Berbagai Macam Penggunaan Lahan. World Agroforestry Center. Bogor. Indonesia. $77 \mathrm{hlm}$.

Kauffman, J.B., Donato, D.C., 2012. Protocols for the measurement, monitoring and reporting of structure, biomass and carbon stocks in mangrove forests. Working Paper 86. CIFOR, Bogor, Indonesia.

Landerdale, F.T. and Savanah. 1998. Spectrum Laboratories : Chemical Fact Sheet. Spectrum Laboratories, Inc. GA, USA. Chemical Abstract number 1071836.

Moenandir, J. 1990. Pengantar Ilmu Pengendalian Gulma. Rajawali Press. Jakarta.

Monde A, N Sinukaban, K Murtilaksono dan N H Pandjaitan, 2008. Dinamika Kualitas Tanah, Erosi dan Pendapatan Petani Akibat Alih Guna Lahan Hutan menjadi Lahan Kakao di DAS Nopu, Sulawesi Tengah. J. Forum Pascasarjana IPB. Sekolah Pascasarjana IPB, Bogor, pp. 215-225.

Parapasan, Y., R. Subiantoro, dan M. Utomo. 1995. Pengaruh Sistem Olah Tanah terhadap Kekerasan dan Kerapatan Lindak Tanah pada Musim Tanam XVI. Prosiding. Sem. Nas-V BDP-OTK. Universitas Lampung. Bandar Lampung. hal 78-82.
Sarief, E.S. 1989. Konservasi Tanah dan Air. Pustaka Buana. Bandung.

Utomo, M., H. Suprapto dan Sunyoto. 1989. Influence of tillage dan nitrogen fertilization on soil nitrogen, decomposition of alangalang (Imperata cylindrica) dan corn production of alang-alang ldan. In: J. van der Heide (ed.). Nutrient Management for Food Crop Production in Tropical Farming Systems. Institute for Soil Fertility (IB), Heren, The Nedtherldans, dan Universitas Brawijaya, Malang. pp. 367-373. 